\title{
KOLABORASI PENELITI DI ERA TEKNOLOGI INFORMASI DAN KOMUNIKASI
}

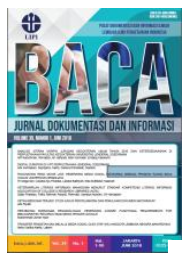

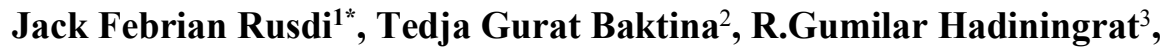 \\ Budi Sunaryo $^{4}$, Puteri Fannya ${ }^{5}$, Fretycia Laurenty ${ }^{6}$ \\ ${ }^{1}$ Sekolah Tinggi Teknologi Bandung, Indonesia \\ ${ }^{2}$ Dinas Pendidikan Kota Bandung, Indonesia \\ ${ }^{3}$ Human Geography, University of Exeter, United Kingdom \\ ${ }^{4}$ Universitas Bung Hatta, Indonesia \\ ${ }^{5}$ Fakultas Ilmu Kesehatan, Universitas Esa Unggul, Indonesia \\ ${ }^{6}$ Manajemen Pendidikan Islam, STITNU Sakinah Dharmasraya, Indonesia
}

*Korespondensi: jack@sttbandung.ac.id

Diajukan: 08-08-2019; Direview: 20-01-2020; Diterima: 03-02-2020; Direvisi: 10-02-2020

\begin{abstract}
Advances in information and communication technology have an impact on increasing the number of scientific publications in the world. Scientific papers are an indicator of a country's progress in the academic field. One strategy used to improve the quality of scientific publications is through collaboration between researchers. From various study result searches, there are not many studies that discuss the collaboration of researchers. The purpose of this study is to produce one of the fundamental studies on research development in Indonesia. The method used in this study is the study of literature. This article contributes to the collaboration picture of researchers, including the background of collaboration and aspects that affect collaboration, as well as the contribution of Indonesian research in terms of information technology to support research for researcher.
\end{abstract}

\begin{abstract}
ABSTRAK
Kemajuan teknologi informasi dan komunikasi berdampak pada peningkatan jumlah publikasi ilmiah di dunia. Publikasi ilmiah merupakan indikator kemajuan suatu negara di bidang akademik. Salah satu strategi yang digunakan untuk meningkatkan kualitas publikasi ilmiah adalah melalui kolaborasi antarpeneliti. Dari berbagai pencarian hasil studi, tidak banyak kajian yang membahas tentang kolaborasi para peneliti. Tujuan dari studi ini adalah menghasilkan salah satu dasar kajian tentang pengembangan penelitian di Indonesia. Metode yang digunakan dalam kajian ini adalah studi literatur. Artikel ini memberikan kontribusi tentang gambaran kolaborasi peneliti meliputi latar belakang kolaborasi dan aspek yang memengaruhi kolaborasi, serta kontribusi penelitian Indonesia dari sisi teknologi informasi untuk mendukung penelitian bagi peneliti.
\end{abstract}

Keywords: Research collaboration; Researcher behaviour; Information; Communication; Technology; Indonesia

\section{PENDAHULUAN}

Era akselerasi teknologi informasi dan komunikasi memberikan pengaruh di berbagai bidang (Xiang 2018; Febrian 2007, 2008), termasuk tingginya pertumbuhan hasil publikasi ilmiah yang ada di dunia, baik melalui penelitian individual maupun kolaborasi (Cundill, et al., 2019). Berbagai hasil penelitian akademisi di suatu negara memberikan dampak yang signifikan bagi negara maju seperti Jepang, China, Amerika, dan negara Eropa (Christensen, Gornitzka, \& Ramirez, 2018; Rusdi, Salam, Abu, Baktina, et al., 2019).

Banyak negara berkompetisi untuk menunjukkan kepada dunia tentang eksistensi penelitian yang telah mereka hasilkan - karena penelitian akademik mampu menjadi pengendali pertumbuhan ekonomi dan perubahan sosial masyarakat (Klofsten, et al. 2019; 
Febrian, 2000). Publikasi ilmiah merupakan tolak ukur kemajuan suatu negara dari sisi akademik (Tuhuteru \& Iriani 2018; Nasution 2017). Indonesia pun meningkatkan pertumbuhan publikasi ilmiah di level nasional dan internasional, seperti melalui berbagai program yang dilaksanakan oleh pemerintah (Nashihuddin \& Aulianto, 2016; Achsan, 2014; Handoyo, et al. 2012; Rusdi, Salam, Abu, \& Baktina, et al., 2019).

Kolaborasi peneliti merupakan langkah strategis untuk menghasilkan penelitian yang memberikan dampak ke berbagai aspek (Klofsten, et al., 2019; Rusdi, 2017), termasuk didalamnya meningkatkan peringkat suatu perguruan tinggi secara internasional dan meningkatkan peringkat negara di mata dunia (Achsan, 2014). Selain itu, hasil penelitian menjadi tolok ukur keprofesionalan peneliti itu sendiri dibidangnya (Lukitaningtias \& Hernanik, 2018; Maryono \& Surajiman, 2017).

Namun, ketika artikel ini ditulis, penulis tidak mudah menemukan penelitian tentang kolaborasi peneliti secara menyeluruh baik di publikasi nasional maupun internasional.Kajian tentang peneliti mendapat perhatian yang tidak banyak dari riset yang dihasilkan, apalagi jika kajian dipertajam kepada kolaborasi peneliti. Artikel ini mengkaji tentang kolaborasi peneliti bidang teknologi informasi dan komunikasi. Metode yang digunakan adalah studi literatur dari berbagai artikel ilmiah, baik nasional maupun internasional. Untuk kasus spesifik terkait perkembangan publikasi di Indonesia, referensi yang digunakan adalah penelitian yang ada di Indonesia. Kajian ini meliputi latar belakang yang mempengaruhi terbentuknya kolaborasi peneliti, tujuan kolaborasi peneliti, perilaku, dsb. Tujuan penelitian ini untuk menyediakan informasi bagi peneliti lain terkait peningkatan hasil penelitian secara berkolaborasi di Indonesia.

\section{TINJAUAN PUSTAKA}

Kemajuan teknologi informasi dan komunikasi telah membuat peneliti semakin mudah untuk mengakses pihak penerbit dalam mempublikasikan hasil penelitian mereka, baik sebagai media publikasi maupun sebagai sumber informasi penelitian (Azwar \& Amalia 2017; Yanti \& Ika, 2018). Dalam dunia penerbitan, bentuk publikasi berubah, dari cetak ke elektronik yang banyak diminati oleh peneliti (Nur'aini, 2013). Pemerintah juga menekankan pemanfaatan jurnal berbasis elektronik (Azwar \& Amalia, 2017). Beberapa standar peringkat dunia juga mengandalkan kemampuan teknologi ini untuk menggali parameter penilaian. Seperti yang diberlakukan dalam pemeringkatan perguruan tinggi secara internasional, yang berdampak pada peringkat negara di mata dunia, maupun profesionalisme peneliti berdasarkan bidang kajian penelitiannya (Achsan, 2014; Nasution 2017; Natakusumah, 2014).

Studi tentang kolaborasi penulis menjadi hal yang menarik bagi beberapa peneliti. Apabila meninjau tiga tahun terakhir sejak 2017, peneliti Indonesia yang mengkaji tentang penelitian secara kolaborasi ini berasal dari berbagai instansi, misalnya dari lembaga pemerintah (Wulan, 2017; Rahayu \& Tupan, 2018; Widuri \& Prasetyadi, 2018; Yaman, et al., 2019; Maha \& Tupan, 2019) dan perguruan tinggi (Rohanda \& Winoto 2019; Sholihah 2018; Rokhmah \& Anggorowati, 2017). Peneliti berasal dari berbagai disiplin ilmu, seperti Ilmu Komputer (Nasution, 2017), Sistem Informasi (Tuhuteru \& Iriani, 2018), Perpustakaan dan Informasi (Rahayu \& Tupan, 2018; Himawanto, 2017; Rasmila 2017), Ekonomi dan Bisnis (Mafra, Suhada, \& Sinarti, 2018; Lukitaningtias \& Hernanik 2018), Teknik Industri (Arvianto, et al., 2019), serta Kepemimpinan dan Kebijakan (Seftyono, 2018). 


\subsection{Peneliti dan Penelitian}

Peneliti adalah orang yang meneliti dengan menggunakan metode ilmiah dan sistem tertentu dalam memperoleh pengetahuan (Syarianah, 2016). Suatu penelitian dianggap belum selesai apabila belum dipublikasikan pada terbitan jurnal ilmiah, berkualitas, dan terakreditasi. Jurnal yang berkualitas dapat dicek daftar jurnal internasional yang terindeks di Thomson Reuters atau Scopus (Natakusumah, 2014; Sofyani \& Nazaruddin, 2019). Kualitas terbitan jurnal ini menjadi salah satu tugas peneliti - dalam penelitian dan pengembangan pengetahuan dan teknologi (Syarianah, 2016). Peneliti dapat berasal dari akademisi (dosen, guru, mahasiswa) (Syarianah, 2016; Nappu, Dewi, \& Daddi, 2019), balitbang kementrian, dan balitbang non-kementrian (Syarianah, 2016). Perguruan tinggi berupaya menjaga dan meningkatkan keunggulan kompetitif, diantaranya dengan menerapkan sistem pengukuran kinerja bagi dosen (Sofyani \& Nazaruddin, 2019). Kompetensi yang menjadi motivasi bagi dosen diantaranya profesionalisme dan kepribadian (Mafra, Suhada, \& Sinarti, 2018). Bagi guru, penelitian merupakan salah satu bentuk pelaksanaan jabatan fungsional dan angka kreditnya diantaranya melalui penelitian tindakan kelas (Nappu, Dewi, \& Daddi, 2019). Bagi Kepala sekolah dan pengawas, penelitian lebih cenderung pada tindakan sekolah (Windayana, 2016).

\subsection{Kolaborasi Penelitian}

Penelitian dunia secara berkolaborasi meningkat dari waktu kewaktu dibandingkan dengan penelitian yang dilakukan secara individual (Dong, et al., 2018), begitu juga dengan penelitian lokal yang ada di Indonesia (Maryono \& Junandi 2012; Rohanda \& Winoto 2019; Rahmawati \& Thalia, 2013). Kolaborasi merupakan perkumpulan individu yang bekerja untuk menuju satu tujuan dan peneliti dapat dikatakan berkolaborasi apabila ikut memberikan kontribusi penting pada suatu penelitian (Handoyo, et al., 2012). Aktivitas kolaborasi ini mampu memberikan dampak signifikan pada usaha kolektif manusia (Herdiani \& Sastramihardja, 2011). Kolaborasi memberikan peran untuk mempraktekan sesuatu atau berinteraksi antar sesama (Nalbaho, 2015).

Tingkat kolaborasi penulis sudah dilakukan oleh peneliti nasional (Maryono \& Junandi, 2012; Rohanda \& Winoto, 2019; Syarianah, 2016), dalam jurnal yang diteliti, tingkat kolaborasi cukup tinggi mencapai 94,22\% (Syarianah, 2016). Artikel ditulis secara kolaborasi dengan tiga penulis merupakan yang paling banyak ditemukan (Syarianah, 2016; Safitri, 2011; Rohanda \& Winoto, 2019).

Penelitian dapat memberikan nilai berlipat bagi suatu institusi apabila dilakukan secara berkolaborasi, untuk itu disarankan melakukan penelitian secara berkolaborasi (Achsan, 2014). Kolaborasi peneliti secara internasional berdampak positif terhadap kinerja penelitian (Abramo, D'Angelo, \& Costa, 2019). Permasalahan lain yang kadang muncul adalah beban yang sering menjadi kendala bagi peneliti, yaitu tingginya biaya koordinasi riset antarlembaga atau bahkan untuk kolaborasi internasional (Handoyo, et al., 2012).

Komunitas peneliti berasal dari beragam kelompok ilmu memiliki ketertarikan pada topik tertentu (Nalbaho, 2015). Kolaborasi ini merupakan aliran pengaruh mulai dari personal characteristic, behavior, hingga job performance (Nurdinintya \& Tien, 2015). Kolaborasi penelitian terjadi di berbagai bidang seperti seni, industri, teknologi, ilmu pengetahuan, bisnis, pendidikan, dan perancangan perangkat lunak (Herdiani \& Sastramihardja, 2011).

Kegiatan penelitian dapat dilakukan secara individu ataupun berkolaborasi (Farida, 2010). Berbagai bentuk perilaku peneliti ditinjau dari ontologi penelitian (Rusdi, Salam, Abu, Sahib, 
et al., 2019), termasuk dari sisi demografi, seperti usia (Nurdinintya \& Tien, 2015; Cahyani, 2016), gender (Nurdinintya \& Tien, 2015; Abramo, D’Angelo, \& Costa, 2019; Nielsen \& Börjeson, 2019), interaksi (Nurdinintya \& Tien, 2015), komunikasi (Nurdinintya \& Tien, 2015), kondisi psikologis (Nurdinintya \& Tien, 2015), pemrosesan informasi (Nurdinintya \& Tien, 2015), dan latar belakang akademik (Abramo, D’Angelo, \& Costa, 2019; Nielsen \& Börjeson, 2019). Hal yang dapat diciptakan melalui kolaborasi penelitian yaitu kesempatan untuk saling berbagi pengetahuan, keahlian atau teknik tertentu mengenai suatu ilmu, masalah pembagian kerja, dan pemanfaatan keahlian yang efektif untuk meningkatkan produktivitas (Syarianah, 2016).

Kolaborasi penelitian dapat menjadi jembatan kerjasama antar-peneliti dan organisasi, baik dalam hal sumber daya manusia, peralatan, gagasan, dana (Handoyo, et al., 2012). Kolaborasi penelitian seperti dalam hal inovasi umumnya berusaha menambahkan ide-ide, pengetahuan, keahlian, peluang bagi individu dan peluang bagi lingkungannya. Dari sisi peneliti, tahapan yang terkait dengan kolaborasi dimulai dengan adanya motivasi, kemudian berdasarkan pada peluang dan inovasi (Nizar, 2016). Dari hal tersebut praktik kolaborasi dalam memperoleh pengetahuan didapatkan melalui pendidikan, pemikiran, dan filosofis (Syarianah, 2016).

Produktivitas kolaborasi juga dipengaruhi oleh faktor usia, jenis kelamin, masa jabatan, posisi akademik, dan lokasi secara geografis (Maryono \& Surajiman, 2017). Karakteristik kolaborasi meliputi dashboard, rule, event, history, membership, dan iteraction (Herdiani \& Sastramihardja, 2011). Kolaborasi peneliti juga terdiri atas beberapa elemen, yaitu: participant (Herdiani \& Sastramihardja, 2011), role (Herdiani \& Sastramihardja, 2011), abstract service (Herdiani \& Sastramihardja, 2011), strategi institusi, pendanaan atau resource, infrastruktur dan organisasi pendukung, mutual, dan pengembangan keberlanjutan (Castro, Nagano, \& Ribeiro, 2019). Model kolaborasi dapat dilakukan dalam bentuk library collaboration model, solicitation collaboration model, team collaboration model, community collaboration model, dan process support collaboration model (Herdiani \& Sastramihardja, 2011). Dalam pengembangan kolaborasi ada beberapa tahap, yaitu mengidentifikasi elemen, elemen dan karakteristik yang dibangun, menciptakan elemen baru, serta menghubungkan berbagai elemen yang ada (Herdiani \& Sastramihardja, 2011).

\section{METODE}

Metode penelitian dilakukan dengan studi literatur. Literatur diprioritaskan hasil riset di tiga tahun terakhir, kecuali sebagai hal yang fundemental, waktu publikasi sumber data dapat melebih batas waktu tersebut. Tahapan penelitian ini yaitu pengumpulan data, pengolahan data, dan analisis data. Pengumpulan data diambil dari berbagai artikel penelitian yang berasal dari database online, seperti ScienceDirect, Google Scholar, dan Garuda Ristek-Dikti, yang terkait dengan "kolaborasi penelitian" dan "teknologi informasi komunikasi". Artikel yang terkumpul kemudian diseleksi. Artikel yang digunakan berasal dari artikel nasional, dalam bentuk jurnal, tesis, prosiding, skripsi, dan buku. Beberapa artikel juga diambil dari artikel penelitian internasional untuk membandingkan analisis datanya. Artikel yang telah diseleksi menjadi bahan analisis data. Tahapan penelitian melalui tiga tahap, yaitu pra riset, pelaksanaan riset, dan pasca riset (Gambar 1. Tahapan penelitian (2020) 


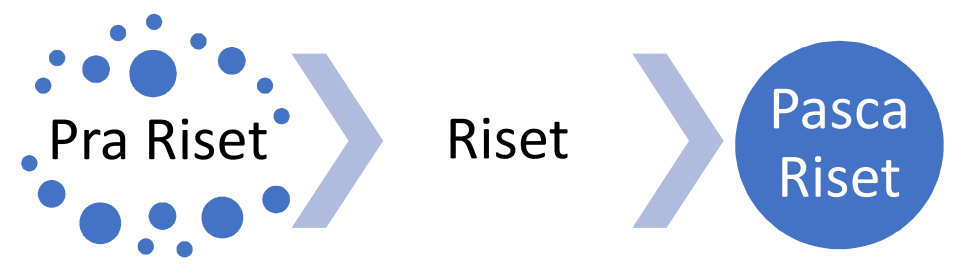

Gambar 1. Tahapan penelitian (2020)

- Pra-riset - kegiatan yang dilakukan sebelum riset dilaksanakan, mencakup: menentukan apa yang akan diriset (Kumar, 2010), perencanaan, mempelajari literatur, dan membuat perencanaan riset (Mertler, 2017).

- Pelaksanaan riset - mulai dari perencanaan sampai riset tersebut dipublikasi, mencakup: pengonsepan riset (Kumar, 2010), konstruksi data, mengumpulkan dan analisis data (Mertler, 2017; Kumar, 2010), membuat langkah aksi dengan mempertajam langkah berikutnya serta lingkaran penelitian untuk masa yang akan datang, dan membuat laporan penelitian (Mertler, 2017).

- Pasca-riset - ketika riset telah selesai dilaksanakan, mencakup: berbagi informasi dan refleksi atas riset (Mertler 2017) dan melibatkan stakeholder untuk evaluasi (Kumar, 2010).

\section{HASIL DAN PEMBAHASAN}

\subsection{Pengaruh Kolaborasi}

Penelitian secara kolaborasi antar-penulis disebabkan oleh berbagai faktor, yaitu faktor personal, profesional, dan organisasi (Gambar 2).

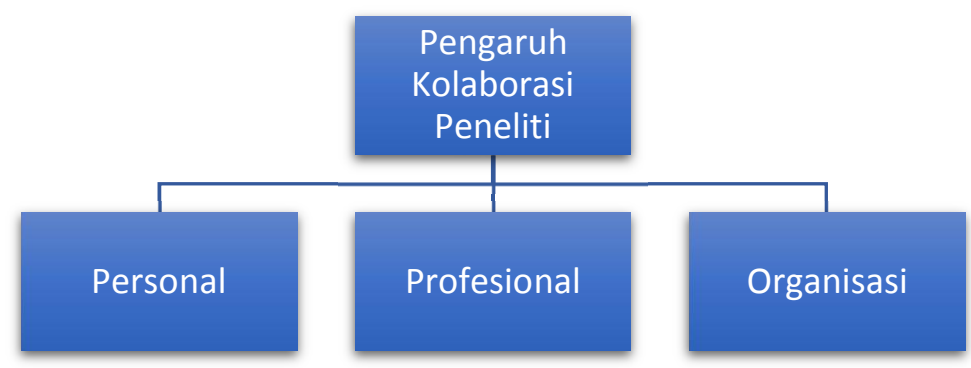

Gambar 2. Pengaruh kolaborasi peneliti (2020)

Berikut ini ada beberapa alasan kolaborasi:

1) Faktor Personal:

- Karakteristik kepribadian (Lukitaningtias \& Hernanik, 2018; Bukvova, 2010).

- Persepsi (Lukitaningtias \& Hernanik, 2018).

- Motivasi dan kepercayaan diri (Lukitaningtias \& Hernanik, 2018; Sofyani \& Nazaruddin, 2019).

- Sikap tertarik untuk berpartisipasi (Rasmila, 2017; Lukitaningtias \& Hernanik, 2018).

- Komunikasi (Bukvova, 2010).

- Faktor budaya (Lukitaningtias \& Hernanik, 2018).

- Kesadaran akan perbedaan (Bukvova, 2010).

- Keakraban (Bukvova, 2010). 
- Membutuhkan pihak lain (Rasmila, 2017).

- Perhatian antar-anggota (Bukvova, 2010).

- Lingkungan yang mendukung (Lukitaningtias \& Hernanik, 2018).

- Berbagi pengalaman (Nalbaho, 2015).

- Belajar keterampilan baru (Rasmila, 2017; Nalbaho, 2015).

- Menambah wawasan (Prasetyadi \& Nugroho, 2014).

- Tujuan khusus (Rasmila, 2017).

- Prestisius (Bukvova, 2010).

- Sebagai hiburan dan kesenangan (Bukvova, 2010).

- Akses pendanaan (Rasmila, 2017).

- Kompensasi dan penghargaan yang diterima (Bukvova, 2010; Lukitaningtias \& Hernanik, 2018)

- Pemenuhan kebutuhan (Lukitaningtias \& Hernanik, 2018).

- Demografis (Lukitaningtias \& Hernanik, 2018).

- Kepuasan kerja (Lukitaningtias \& Hernanik, 2018).

- Stress kerja (Lukitaningtias \& Hernanik, 2018).

- Konflik (Lukitaningtias \& Hernanik, 2018).

- Komitmen untuk berkinerja (Sofyani \& Nazaruddin, 2019).

- Meningkatkan popularitas (Rasmila, 2017).

2) Faktor Profesional

- Latar belakang (Lukitaningtias \& Hernanik 2018).

- Kerapian (Bukvova, 2010).

- Pengalaman dan keterampilan (Lukitaningtias \& Hernanik, 2018).

- Desain pekerjaan (Lukitaningtias \& Hernanik, 2018).

- Perspektif baru bagi peneliti (Prasetyadi \& Nugroho, 2014).

- Batasan kolaborasi (Bukvova, 2010).

- Kualitas issue penelitian (Bukvova, 2010).

- Pemecahan masalah yang kompleks (Bukvova, 2010).

- Meningkatkan produktivitas (Bukvova, 2010).

- Akses sumber daya (Rasmila, 2017; Bukvova, 2010).

- Kegiatan proyek (Rasmila, 2017).

- Kepercayaan dan kecocokan kerja (Rasmila, 2017).

- Hubungan keahlian (Bukvova, 2010).

- Kontribusi (Rasmila, 2017).

- Menjaga aktivitas lebih fokus (Rasmila, 2017).

- Kemampuan keahlian (Lukitaningtias \& Hernanik, 2018).

- Berbagi pengetahuan dan keahlian (Syarianah, 2016).

- Berbagi teknik dan keterampilan baru (Syarianah, 2016; Nalbaho, 2015; Bukvova, 2010).

- Pertukaran ide dan informasi antar-disiplin ilmu (Rasmila, 2017; Nalbaho, 2015).

- Penelitian lebih fokus (Bukvova, 2010).

- Pengembangan karir (Lukitaningtias \& Hernanik, 2018).

- Meningkatkan kualitas hasil (Rasmila, 2017). 
3) Organisasi

- Struktur dan desain organisasi (Lukitaningtias \& Hernanik, 2018).

- Kebijakan administrasi (Sofyani \& Nazaruddin, 2019).

- Tujuan yang jelas dalam organisasi (Lukitaningtias \& Hernanik, 2018).

- Sumber daya organisasi (Bukvova, 2010; Lukitaningtias \& Hernanik, 2018).

- Perhatian dan dukungan institusi (Rasmila, 2017; Bukvova, 2010).

- Peraturan dan tanggung jawab (Rasmila, 2017).

- Berbagi beban kerja dan pengurangan beban mengajar (Rasmila, 2017; Lukitaningtias \& Hernanik, 2018).

- Faktor politis (Rasmila, 2017).

- Legitimasi lembaga (Bukvova, 2010).

- Kepemimpinan dan kekuasaan (Bukvova, 2010; Lukitaningtias \& Hernanik, 2018).

- Koordinasi (Bukvova, 2010).

- Kultur organisasi (Bukvova, 2010).

- Pendanaan (Bukvova, 2010).

- Ukuran kelompok (Bukvova, 2010).

- Tingkatan institusi (Bukvova, 2010).

- Afiliasi dari lembaga riset (Bukvova, 2010).

- Kolaborasi nasional dan internasional (Bukvova, 2010).

\subsection{Cikal Bakal Terbentuk Kolaborasi}

Kolaborasi terjadi melalui peristiwa yang tidak disengaja ataupun disengaja. Keterlibatan dalam bentuk disengaja juga memungkinkan dengan menghubungi peneliti lain melalui email, telepon, atau alat komunikasi lainnya (Beaver, 2001).

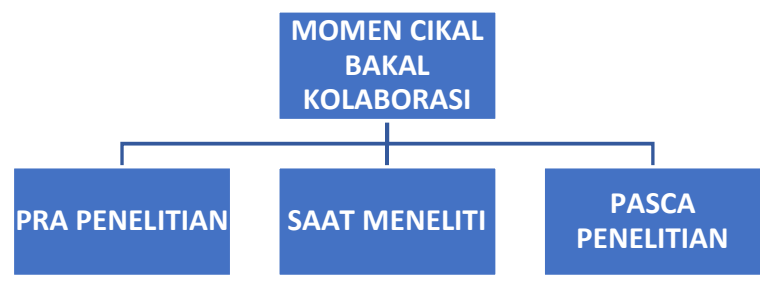

Gambar 3. Cikal bakal kolaborasi terbentuk (2020)

Gambar 3 menunjukkan bahwa cikal bakal kolaborasi terjadi melalui tiga tahapan waktu, yaitu:

- Pra-penelitian, yaitu saat penelitian akan dilaksanakan. Hal ini dapat terjadi melalui interaksi, berbagi informasi, atau melalui aktivitas koordinasi yang menitikberatkan kompetensi dan sumber daya (Handoyo, et al., 2012), disamping kegiatan ilmiah seperti pada kegiatan perkuliahan, kolokium, seminar, konferensi, presentasi, tugas bersama, dan pada saat dilakukan kunjungan kerja (Beaver, 2001).

- Saat penelitian, yaitu saat penelitian berlangsung, seperti halnya pada kejadian prapenelitian, misalnya pada saat sosialisasi penelitian (Handoyo, et al., 2012; Beaver, 2001).

- Pasca-penelitian, yaitu pada saat penelitian selesai dilaksanakan, dan diperlukan tindak lanjut dari penelitian sebelumnya, seperti melanjutkan dalam kajian tertentu (Nalbaho, 
2015). Keberlanjutan riset biasanya ditentukan oleh finansial, manajemen organisasi, pendukung riset, dan infrastruktur (Arvianto, et al., 2019).

\subsection{Aspek Kolaborasi Penelitian}

Beberapa aspek yang mendasari kolaborasi penelitian ini dapat dilihat dari tujuan kolaborasi, bentuk kontribusi, keterlibatan dalam kolaborasi penelitian, kategori kolaborasi, model kolaborasi, tahapan pengembangan kolaborasi, proses kolaborasi, serta hal-hal yang dapat diciptakan melalui kolaborasi itu sendiri. Tujuan kolaborasi (Gambar 2), yaitu:

- Personal (Beaver 2001), mencakup pendanaan, berbagi kebahagiaan, mengurangi tingkat keterkucilan, meningkatkan energi dan semangat, dan hiburan dan kesenangan.

- Profesional, mencakup: jalur keahlian; kebanggan dan visibilitas untuk menuju profesionalisme; efisiensi; kemajuan lebih cepat; penanganan masalah yang lebih besar, penting, komprehensif, tingkat kesulitan yang lebih tinggi, serta permasalahan global; meningkatkan produktivitas penelitian; menciptakan jaringan; mempelajari alat, keahlian, dan permasalahan baru; memuaskan rasa keingintahuan secara intelektual; menyempurnakan penelitian dengan efisien dalam rangka mengurangi tingkat kesalahan; fokus pada penelitian karena partner dapat mengerjakan pekerjaan lainnya; mendidik mahasiswa atau bawahan maupun diri sendiri (Beaver, 2001); melakukan inovasi (Nizar, 2016); bertukar pengalaman (Nalbaho, 2015); belajar meningkatkan pengetahuan (Beaver, 2001); belajar bersama; belajar memecahkan permasalahan secara praktis; bertukar informasi; berinteraksi antar-sesama (Nalbaho, 2015); path to enterpreneurs (Castro, Nagano, \& Ribeiro, 2019); external relation for knowledge sharing (Castro, Nagano, \& Ribeiro 2019); mutual penelitian dengan aspek lainnya (Castro, Nagano, \& Ribeiro, 2019).

- Organisasi, mencakup: jalur untuk Peralatan, sumber daya, serta bahan yang tidak dimiliki (Beaver, 2001); strategi universitas; leadership in organization; measure in university impact; dan sumberdaya (Castro, Nagano, \& Ribeiro, 2019).

\subsection{Kontribusi Antar-Peneliti}

Bentuk kontribusi antar-peneliti dalam berkolaborasi, yaitu: bertanggung jawab pada satu atau lebih elemen penelitian; kontribusi pada eksperimen penelitian; analis dan interpretasi data; penulisan laporan; hasil penelitian; kontribusi pada tahapan pencetusan ide; kontribusi pada tahapan hipotesis; kontribusi pada tahapan interpretasi teori; kontribusi sebagai pemilik proposal asli; kontribusi sebagai penyandang dana (Handoyo, et al., 2012); kontribusi berupa ilmu pengetahuan (Syarianah, 2016); menyumbangkan tindakan intelektual (Syarianah, 2016); dan berpartisipasi dalam materi (Syarianah, 2016; Castro, Nagano, \& Ribeiro 2019).

\subsection{Keterlibatan Peneliti}

Kolaborasi penelitian melibatkan para peneliti dengan ruang lingkup peneliti sebagai berikut (Gambar 4). 


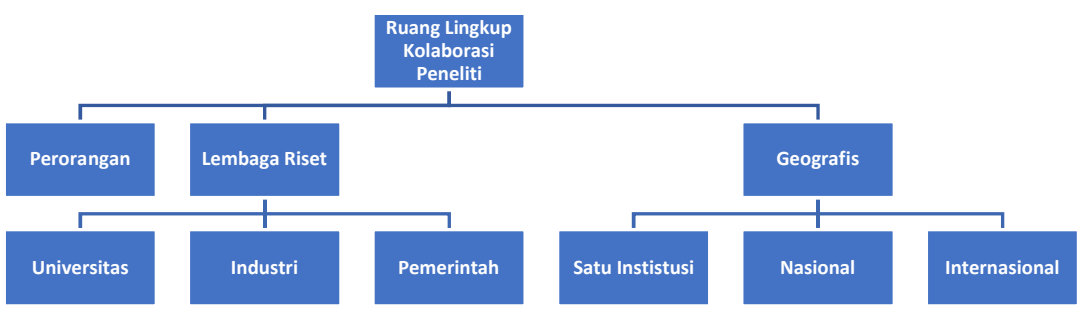

Gambar 4. Ruang lingkup kolaborasi para peneliti (2020)

1) Orang: dosen dengan mahasiswa; pengawas dengan asisten; Peneliti dengan konsultan (Subramanyam, 1983); dan antar teman sejawat dalam satu institusi (Subramanyam 1983; Abramo, D'Angelo, \& Costa, 2019).

2) Lembaga riset (Syarianah 2016; Subramanyam 1983; Bukvova 2010); universitas; industri; dan pemerintah (Castro, Nagano, \& Ribeiro 2019).

3) Geografis: (a) dalam satu institusi (Maryono \& Surajiman, 2017; Bukvova, 2010): internal (Maryono \& Surajiman, 2017); dengan departemen lain pada kampus tersebut (Abramo, D'Angelo, \& Costa, 2019); (b) domestik /nasional (Maryono \& Surajiman, 2017; Abramo, D'Angelo, \& Costa 2019; Bukvova, 2010); (c) Internasional (Maryono \& Surajiman, 2017; Abramo, D’Angelo, \& Costa, 2019; Bukvova, 2010; Subramanyam, 1983).

\subsection{Kategori Kolaborasi Penelitian}

Kategori kolaborasi penelitian, mencakup:

1) Collaborative network (Herdiani \& Sastramihardja, 2011; Cundill, Currie-Alder, \& Leone, 2019).

2) Common goal (Herdiani \& Sastramihardja, 2011; Camarinha-Matos \& Afsarmanesh, 2006).

3) Relationship, termasuk competition, group of interest, supplier-costumer, exchange/sharing (Herdiani \& Sastramihardja, 2011).

4) Topology, seperti star, chain, peer to peer, duration (continuous, discontinuous) dan power (central, equal, hierarchic)) (Herdiani \& Sastramihardja, 2011).

\subsection{Penelitian Kolaborasi Pada Terbitan Nasional}

Penelitian tentang kolaborasi pada jurnal nasional telah dilakukan dalam berbagai bentuk (Rusdi, 2019), sebagaimana terlihat pada Table 1.

Table 1. Penelitian tentang Kolaborasi Peneliti Nasional atau Jurnal Nasional

\begin{tabular}{|l|l|c|}
\hline \multicolumn{1}{|c|}{ Judul Penelitian dan Penulis } & \multicolumn{1}{|c|}{ Objek Terbitan } & $\begin{array}{c}\text { Kolaborasi } \\
\text { Penulis }\end{array}$ \\
\hline $\begin{array}{l}\text { Kolaborasi dan produktivitas pengarang tahun 2006- } \\
\text { 2009 (Farida, 2010) }\end{array}$ & $\begin{array}{l}\text { Jurnal D-Lib Magazine } \\
\text { Jurnal Information Research }\end{array}$ & $64 \%$ \\
\hline $\begin{array}{l}\text { Kolaborasi pengarang tahun 2006-2010 (Safitri, } \\
\text { 2011) }\end{array}$ & $\begin{array}{l}\text { The International Journal of } \\
\text { Geomechanics }\end{array}$ & $89 \%$ \\
\hline $\begin{array}{l}\text { Analisis kolaborasi dan institusi tahun 2007-2011 } \\
\text { (Maryono \& Junandi, 2012) }\end{array}$ & $\begin{array}{l}\text { Indonesian Journal of } \\
\text { Chemistry }\end{array}$ & $82 \%$ \\
\hline $\begin{array}{l}\text { Produktivitas dan tingkat kolaborasi penulis tahun } \\
\text { 2005-2010 (Wulan, 2014) }\end{array}$ & $\begin{array}{l}\text { Bidang Zoologi- Puslit Biologi } \\
\text { LIPI }\end{array}$ & $84 \%$ \\
\hline Kolaborasi kepakaran peneliti yang diambil dari & Jurnal Inkom & $76.47 \%$ \\
\hline
\end{tabular}




\begin{tabular}{|l|l|c|}
\hline $\begin{array}{l}\text { data pada Jurnal Ilmiah LIPI bidang Informatika dan } \\
\text { Kebumian (Prasetyadi \& Nugroho, 2014) }\end{array}$ & $\begin{array}{l}\text { Jurnal Riset Geologi \& } \\
\text { Pertambangan }\end{array}$ & $66.66 \%$ \\
\hline $\begin{array}{l}\text { Analisis blibiometrika penulis jurnal kolaborasi dan } \\
\text { sitasi tahun 2011-2012 (Pohan, 2014) }\end{array}$ & $\begin{array}{l}\text { International Journals on } \\
\text { Electrical Engineering and } \\
\text { Informatic } \\
\text { ITB Journals of Engineering } \\
\text { Science }\end{array}$ & $78 \%$ \\
\hline $\begin{array}{l}\text { Kolaborasi dan produktivitas peneliti tahun 2000- } \\
\text { 2014 (Rahayu \& Rachmawati, 2016) }\end{array}$ & Jurnal Visi Pustaka & $80 \%$ \\
\hline $\begin{array}{l}\text { Riset konsorsium energi, karya yang diterbitkan } \\
\text { pada periode 2010-2011 (Himawanto, 2016) }\end{array}$ & $\begin{array}{l}\text { 14 Jurnal bereputasi melalui } \\
\text { ScienceDirect bidang energi }\end{array}$ & $3.87 \%$ \\
\hline $\begin{array}{l}\text { Produktivitas peneliti pusat penelitian dan } \\
\text { pengembangan perikanan tahun 2007-2011 } \\
\text { (Syarianah, 2016) }\end{array}$ & Jurnal Riset Akuakultur & $94.22 \%$ \\
\hline $\begin{array}{l}\text { Tingkat dan alasan pengarang berkolaborasi tahun } \\
\text { 2012-2016 (Rasmila, 2017) }\end{array}$ & $\begin{array}{l}\text { Jurnal Reference Service } \\
\text { Review }\end{array}$ & $55 \%$ \\
\hline $\begin{array}{l}\text { Penelitian secara kolaborasi tahun 2006-2014 } \\
\text { (Suryantini \& Nurdiana, 2017) }\end{array}$ & Jurnal AgroBiogen \\
\hline $\begin{array}{l}\text { Tingkat kolaborasi penulis tahun 2006-2016 } \\
\text { (Wulan, 2017) }\end{array}$ & Jurnal Treubia & $85 \%$ \\
\hline $\begin{array}{l}\text { Kolaborasi ilmiah bidang kesehatan Indonesia } \\
\text { (Himawanto, 2017) }\end{array}$ & $\begin{array}{l}\text { ScienceDirect, bidang } \\
\text { Kesehatan }\end{array}$ & $70 \%$ \\
\hline $\begin{array}{l}\text { Kolaborasi dan produktivitas penulis periode 2013- } \\
\text { 2017 (Rahayu \& Tupan, 2018) }\end{array}$ & $\begin{array}{l}\text { Prosiding Lokakarya Nasional } \\
\text { Dokumentasi dan Informasi }\end{array}$ & $63.64 \%$ \\
\hline $\begin{array}{l}\text { Perilaku penulis yang bekerja secara kolaborasi pada } \\
\text { tahun 2013-2014 (Rohanda \&Ruslina, 2018) }\end{array}$ & Jurnal Sosiohumaniora & $\begin{array}{l}0,5 \% \\
63.9 \%\end{array}$ \\
\hline Kolaborasi penulis tahun 2011-2016 (Rahayu, 2018) & $\begin{array}{l}\text { Berita Biologi Jurnal Ilmu- } \\
\text { Ilmu Hayati }\end{array}$ & $78 \%$ \\
\hline $\begin{array}{l}\text { Tingkat kolaborasi penulis (Widuri \& Prasetyadi, } \\
\text { 2018) }\end{array}$ & $\begin{array}{l}\text { Jurnal Mechatronics, Electrical } \\
\text { Power, and Vehacular } \\
\text { Technology }\end{array}$ & $89 \%$ \\
\hline $\begin{array}{l}\text { Derajat kolaborasi penulis jurnal pada tahun 2014- } \\
\text { 2018 (Rohanda \&Winoto, 2019) }\end{array}$ & $\begin{array}{l}\text { Jurnal Kajian Informasi \& } \\
\text { Perpustakaan }\end{array}$ \\
\hline $\begin{array}{l}\text { Pengarang bekerja secara berkolaborasi pada tahun } \\
\text { 2013-2017 (Maha \&Tupan, 2019) }\end{array}$ & $\begin{array}{l}\text { Jurnal Ilmu dan Teknologi } \\
\text { Kayu Tropis }\end{array}$ \\
\hline
\end{tabular}

\subsection{Jurnal Ilmiah di Indonesia}

Tujuan penerbitan terbitan berkala ilmiah yaitu untuk meregistrasi kegiatan kecendekiaan, sebagai sertifikasi terhadap hasil kegiatan ilmiah, mendesiminasikan secara meluas kepada masyarakat dan mengarsipkan temuan (Permendiknas, 2011). Publikasi ilmiah merupakan penghargaan utama terhadap seorang peneliti ataupun akademisi (Heinze \& Kuhlmann, 2008; Handoyo, et al., 2012).

Di Indonesia, muncul Relawan Jurnal Indonesia (RJI) yang merupakan perkumpulan khusus untuk masalah penerbitan jurnal ilmiah. Bentuk relawan sepertinya hanya ada di Indonesia, dan di negara ASEAN tidak ditemukan perkumpulan semacam ini. Tujuan RJI untuk meningkatkan pertumbuhan artikel pada jurnal ilmiah di Indonesia (Seftyono, 2018). Pemerintah dengan berbagai programnya pun berusaha meningkatkan mutu jurnal ilmiah Indoesia, seperti:

1) Dikeluarkannya akreditasi penerbitan oleh pemerintah (Nashihuddin \& Aulianto, 2016).

2) Kerjasama dengan Thomson Reuters agar pendaftaran pada website mereka dapat dilakukan secara gratis termasuk dengan jurnal ProQuest (Achsan, 2014).

3) Memberikan hibah penelitian (Achsan, 2014). 
4) Pembinaan kolaborasi dengan perguruan tinggi lain untuk publikasi hasil penelitian (Achsan, 2014).

5) Stimulus bagi penulis dari pemerintah dalam rangka meningkatkan penelitan berkolaborasi di Indonesia (Handoyo, et al., 2012).

6) Hibah anggaran untuk penelitian melalui Peraturan Menteri Keuangan, dan Riset dan Pengabdian Masyarakat Kementerian Riset Teknologi dan Pendidikan Tinggi (Lukitaningtias \& Hernanik, 2018).

Kehadiran publikasi ilmiah dalam bentuk jurnal cetak serta jurnal elektronik mampu memberikan manfaat bagi para peneliti (Nur'aini, 2013). Apalagi publikasi ilmiah dijadikan sebagai salah satu indikator kemajuan suatu negara terutama dari sisi akademis, dan menjadi indikator kemajuan dari institusi atau perguruan tinggi (Nasution, 2017). Strategi kolaborasi dapat meningkatkan ranking perguruan tinggi Indonesia (Achsan, 2014), dimana indikator pertumbuhan literatur di berbagai ilmu pengetahuan ditinjau dari terbitan berkala (Natakusumah, 2014). Permasalahan yang tidak jarang terjadi pada peneliti adalah tentang adanya ketidakpastian publikasi, sehingga dapat berdampak buruk bagi peneliti di samping itu juga berdampak kepada turunnya kualitas penelitian yang dihasilkan (Handoyo, et al., 2012).

\subsection{Peringkat Perguruan Tinggi Dan Negara Di Dunia}

Universitas memiliki peran yang vital dalam pembangunan suatu negara (Sofyani \& Nazaruddin, 2019). Peringkat perguruan tinggi di level dunia menjadi persaingan bagi berbagai pihak dengan meningkatkan mutu publikasi ilmiah lembaga melalui peringkat tersebut. Peringkat perguruan tinggi secara global dilakukan oleh Times Higher Education, Webometrics, dan Academic Record of World Class University. Metode peringkat perguruan tinggi berdasarkan Times Higher Education dan Quacquarelli Symonds (THE-QS) 60\% berasal dari kualitas penelitian, yang terdiri atas jumlah penelitian yang dihasilkan melalui peer-review serta jumlah sitasi penelitian. Sedangkan Academic Ranking of World University (ARWU) mengalokasikan nilai terkait penelitian dengan komposisi sebesar 80\% (Achsan, 2014). Kinerja dosen sebagai faktor utama pendorong keunggulan kompetitif universitas (Sofyani and Nazaruddin 2019), meskipun dalam beberapa kasus dosen cenderung mengajar dibandingkan dengan melakukan penelitian, mengingat pendapatan dosen berbanding lurus dengan jumlah jam mengajar (Lukitaningtias \& Hernanik, 2018).

Penilaian lembaga riset khususnya perguruan tinggi ditinjau dari performance record, professional qualities, moral features, dan procedural features (Christensen, Gornitzka, \& Ramirez, 2018). Hal tersebut dijelaskan pada Gambar 5.

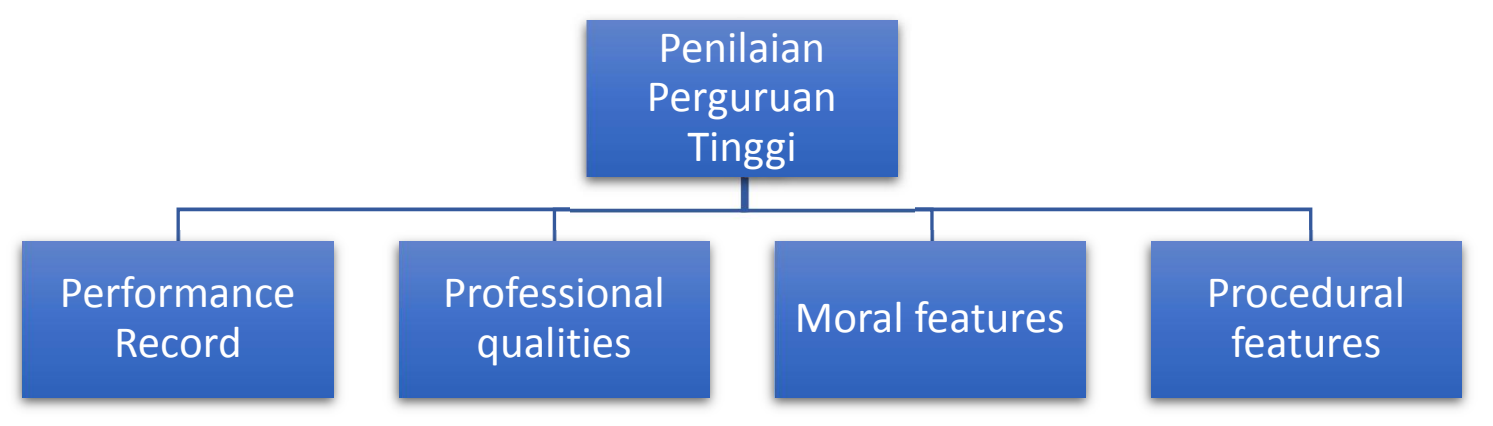

Gambar 5: Penilaian lembaga riset - perguruan tinggi

(Sumber: Adopsi dari Christensen, et al., 2020) 
Selain itu, salah satu kriteria penilaian utama dalam penilaian peringkat perguruan tinggi secara global adalah melalui jumlah sitasi dari dokumen online, sehingga muncul berbagai inisiatif dan program untuk meningkatkan sitasi melalui penelitian kolaborasi antar-peneliti dan antar-lembaga penelitian termasuk perguruan tinggi (Achsan, 2014).

Sitasi berpeluang tinggi apabila terjadi kolaborasi antara berbagai bidang ilmu yang berbeda (Prasetyadi \& Nugroho, 2014). Kolaborasi secara internasional mendapatkan sitasi yang lebih banyak dibandingkan dengan kolaborasi nasional, selain untuk meningkatkan visibilitas artikel dan jurnal (Maryono \& Surajiman, 2017). Satu artikel dapat memberikan jumlah sitasi sesuai dengan jumlah peneliti yang ada pada artikel tersebut (Achsan, 2014).

\subsection{Dukungan Teknologi Informasi Untuk Penelitian}

Terkait kontribusi peneliti Indonesia dalam mengembangkan alat bantu teknologi informasi dan komunikasi untuk pengembangan penelitian, baik penelitian individu maupun kolaborasi, saat ini sudah dilakukan, sebagaimana terlihat pada Table 2.

Table 2. Kontribusi Peneliti Indonesia dengan TIK untuk Pengembangan Penelitian

\begin{tabular}{|l|c|}
\hline \multicolumn{1}{|c|}{ Penelitian } & Tahun \\
\hline Collaborative Network Ontology kolaborasi dinamis (Herdiani \& Sastramihardja, 2011) & 2011 \\
\hline Aplikasi kolaborasi dokumen berbasis web (Bobby \& Wasito, 2013) & 2013 \\
\hline $\begin{array}{l}\text { Kolaborasi dokumen online untuk menaikan peringkat global perguruan tinggi (Achsan, } \\
\text { 2014) }\end{array}$ & 2014 \\
\hline $\begin{array}{l}\text { Pengembangan sistem pakar untuk penelusuran dan publikasi pada jurnal internasional } \\
\text { (Suhardi, Haryoko, \& Jaya 2016) }\end{array}$ & 2016 \\
\hline $\begin{array}{l}\text { Dosen sebagai digital immigran, dan mahasiswa sebagai digital native melalui penelitian } \\
\text { real-time pada cloud computing "Google Apps for Education (GAFE)" (Cahyani, 2016) }\end{array}$ & 2016 \\
\hline $\begin{array}{l}\text { Pengembangan perangkat lunak untuk validasi kategori jurnal internasional terindeks } \\
\text { Scopus maupun jurnal nasional yang terakreditasi (Wahyudi, et al., 2016) }\end{array}$ & 2016 \\
\hline $\begin{array}{l}\text { Melatih mahasiswa untuk melakukan peer-review penelitian mahasiswa dengan } \\
\text { menggunakan Google Docs (Sholihah, 2018) }\end{array}$ & 2018 \\
\hline $\begin{array}{l}\text { Aplikasi pencarian jurnal ilmiah menggunakan metode Term Frequency-Inverse } \\
\text { Document Frequency (Tanari, Handojo, \& Andjarwirawan, 2019) }\end{array}$ & 2019 \\
\hline $\begin{array}{l}\text { Rancang bangun pendaftaran international conference secara online (Febriadi \& Putra, } \\
\text { 2019) }\end{array}$ & 2019 \\
\hline $\begin{array}{l}\text { Sistem informasi untuk menangani penilaian kinerja dosen dengan menggunakan metode } \\
\text { extreme programming (Ricoida, Denny, \& Solihin, 2019) }\end{array}$ & 2019 \\
\hline Penggunaan sistem informasi untuk penilaian beban dosen (Nugraha, et al., 2019) & 2019 \\
\hline
\end{tabular}

\section{KESIMPULAN}

Di era teknologi yang terus berkembang ini, penelitian membuka peluang bagi peneliti untuk lebih dinamis dalam proses publikasi karya ilmiahnya dengan cara berkolaborasi dalam berbagai bentuk. Artikel ini memberikan landasan dasar pengembangan di masa yang akan datang berdasarkan berbagai butir penting yang telah disampaikan pada artikel ini, baik dari hal yang mempengaruhi peneliti untuk melakukan penelitian, latar belakang peneliti melakukan penelitian secara berkolaborasi, dan dampak penelitian bagi institusi, negara, maupun bagi periset sendiri. Penelitian ini diharapkan dapat menjadi salah satu dasar untuk penelitian tentang kolaborasi peneliti di Indonesia. Peneliti menyarankan agar dilakukan pengkajian yang lebih mendalam tentang bagaimana kualitas riset di Indonesia dapat meningkat lebih cepat, sehingga Indonesia dapat menjadi salah satu negara yang semakin disegani hasil penelitiannya oleh dunia. 


\section{DAFTAR PUSTAKA}

Abramo, Giovanni, Ciriaco Andrea D'Angelo, and Flavia Di Costa. 2019. "A Gender Analysis of Top Scientists' Collaboration Behavior: Evidence from Italy.” Scientometrics 120 (2): 405-18. https://doi.org/10.1007/s11192-019-03136-6.

Arvianto, Ary, Meikel Zekben S, Naniek Utami Handayani, Purnawan Adi W, and Singgih Saptadi. 2019. "Pengembangan Indikator Kinerja Utama Untuk Mengukur Keberlanjutan Penelitian Pada Fakultas Teknik Universitas Diponegoro." Jurnal Muara Ilmu Ekonomi Dan Bisnis 2 (2): 263. https://doi.org/10.24912/jmieb.v2i2.857.

Azwar, Muhammad, and Rizka Amalia. 2017. "Pemanfaatan Jurnal Elektronik Sebagai Sumber Referensi Dalam Penulisan Skripsi Di Institut Pertanian Bogor." LIBRARIA: Jurnal Perpustakaan 5 (1): 87. https://doi.org/10.21043/libraria.v5i1.2311.

Beaver, Donald De B. 2001. "Reflections on Scientific Collaboration (and Its Study): Past, Present, and Future." Scientometrics 52 (3): 365-77. https://doi.org/10.1023/A:1014254214337.

Bobby, and Budi Wasito. 2013. "Perancangan Aplikasi Kolaborasi Dokumen Berbasis Web." Jurnal Informatika Dan Bisnis 2 (2): 48-55.

Bukvova, Helena. 2010. "Studying Research Collaboration: A Literature Review." Sprouts: Working Papers on Information Systems 10 (3). http://sprouts.aisnet.org/10-3/.

Cahyani, Intan Putri. 2016. "Adopsi Google Apps For Educationdi Perguruan Tinggi:Sebuah Kolaborasi Real-Timedosen Dan Mahasiswa." Jurnal Penelitian Pers Dan Komunikasi Pembangunan 19 (3).

Camarinha-matos, Luis M., and Hamideh Afsarmanesh. 2006. "Collaborative Networks: Value Creation in a Knowledge Society." In IFIP International Federation for Information Processing, 207:26-40. https://doi.org/10.1007/0-387-34403-9_4.

Castro, Igor Junqueira de, Marcelo Seido Nagano, and Suzana Xavier Ribeiro. 2019. "Elements That Influence Knowledge Sharing in the University-Industry-Government Collaboration." Revista de Gestão 26 (1): 61-72. https://doi.org/10.1108/rege-04-2018-0061.

Christensen, Tom, Åse Gornitzka, and Francisco O. Ramirez. 2018. Reputation Management, Social Embeddedness, and Rationalization of Universities. Universities as Agencies. https://doi.org/10.1007/978-3-319-92713-8_1.

Cundill, G., B. Currie-Alder, and M. Leone. 2019. "The Future Is Collaborative." Nature Climate Change 9 (5): 343-45. https://doi.org/10.1038/s41558-019-0447-3.

Cundill, Georgina, Blane Harvey, Mark Tebboth, Logan Cochrane, Bruce Currie-Alder, Katharine Vincent, Jon Lawn, et al. 2019. "Large-Scale Transdisciplinary Collaboration for Adaptation Research: Challenges and Insights." Global Challenges 3 (4): 1700132. https://doi.org/10.1002/gch2.201700132.

Dong, Yuxiao, Hao Ma, Jie Tang, and Kuansan Wang. 2018. "Collaboration Diversity and Scientific Impact.” ArXiv E-Prints. http://arxiv.org/abs/1806.03694.

Farida, Mutia. 2010. "Kolaborasi Dan Produktivitas Pengarang Bidang Ilmu Perpustakaan Dan Informasi: Studi Kasus Pada Jurnal Online D-Lib Magazine Dan Jurnal Information Research Tahun 2006-2009." Repository Universitas Sumatera Utara. http://repository.usu.ac.id/handle/123456789/18539. 
Febriadi, Bayu, and Pandu Pratama Putra. 2019. "Rancang Bangun Aplikasi E-Register International Conference Berbasis Online Pada Universitas Lancang Kuning." J-SAKTI (Jurnal Sains Komputer Dan Informatika) 3 (1): 132. https://doi.org/10.30645/jsakti.v3i1.109.

Febrian, Jack. 2000. "Buku Saku Tentang Pendidikan Tinggi Di Indonesia.” Penerbit Informatika.

Febrian. 2007. "Google \& Yahoo Secrets!” Penerbit Informatika.

Febrian. 2008. "Menjelajah Dunia Dengan Google.” Penerbit Informatika.

Handoyo, Setiowiji, Prakoso Bhairawa Putera, Pusat Penelitian, Perkembangan Ilmu, Lembaga Ilmu, and Pengetahuan Indonesia. 2012. "Tingkat Kolaborasi Peneliti Pada Program Insentif ' Semi Top - Down' Kementerian Riset Dan Teknologi , Tahun 2008 - 2010 Research Collaboration for Semi Top Down Incentive Program From Ministry of Research and Technology Funding Scheme , Period 2008 - 20.” Warta KIML 10 (10): 99-114.

Harry T Yani Achsan. 2014. "Menaikkan Peringkat Global Perguruan Tinggi Indonesia Melalui Kolaborasi Dokumen Online." Conference: https://www.researchgate.net/publication/292970294_Menaikkan_Peringkat_Global_Pergurua n_Tinggi_Indonesia_Melalui_Kolaborasi_Dokumen_Online.

Heinze, Thomas, and Stefan Kuhlmann. 2008. "Across Institutional Boundaries?. Research Collaboration in German Public Sector Nanoscience." Research Policy 37 (5): 888-99. https://doi.org/10.1016/j.respol.2008.01.009.

Herdiani, Anisa, and Husni S Sastramihardja. 2011. "Ahs: Ontologi Kolaborasi Dinamis." Konferensi Nasional Sistem Informasi Di STMIK Potensi Utama Medan, no. February 2011: $1-8$.

Himawanto, Himawanto. 2016. "Performa Indonesia Pada Riset Konsorsium Energi: Asesmen Bibliometrik Jurnal Ilmiah Internasional.” Berkala Ilmu Perpustakaan Dan Informasi 12 (2): 91. https://doi.org/10.22146/bip.17287.

Himawanto, Himawanto. 2017. "Satu Dasawarsa Kolaborasi Ilmiah Riset Kesehatan Zona Indonesia." Baca: Jurnal Dokumentasi Dan Informasi $38 \quad$ (2): 127. https://doi.org/10.14203/j.baca.v38i2.320.

Klofsten, Magnus, Alain Fayolle, Maribel Guerrero, Sarfraz Mian, David Urbano, and Mike Wright. 2019. "The Entrepreneurial University as Driver for Economic Growth and Social Change - Key Strategic Challenges." Technological Forecasting and Social Change 141 (xxxx): 149-58. https://doi.org/10.1016/j.techfore.2018.12.004.

Kumar, Ranjit. 2010. Research Methodology_A Step-by-Step Guide for Beginners. SAGE Publications Inc.

Lukitaningtias, Firina, and Nova Dwi Hernanik. 2018. "Analisis Faktor Yang Mempengaruhi Kinerja Penelitian Dosen Perguruan Tinggi Swasta ( Pts ) Kluster Madya Di Kota Malang." Arthavidya: Jurnal Ilmiah Ekonomi Universitas Wisnuwardhana Malang 20 (2). https://doi.org/10.29259/jmbs.v16i2.6941.

Mafra, Nisa' Ulul, Suhada, and Tri Sinarti. 2018. "Kajian Model Empiris Kompetensi Profesional Dan Kompetensi Kepribadian Terhadap Motivasi Kerja Serta Implikasinya Pada Kinerja Dosen Universitas Swasta Di Kota Palembang.” Jurnal Manajemen Dan Bisnis Sriwijaya 16 (2). 
Maha, Rahmadani Ningsih, and Tupan Tupan. 2019. "Analisis Referensi Pada Jurnal Ilmu Dan Teknologi Kayu Tropis Tahun 2013-2017.” Baca: Jurnal Dokumentasi Dan Informasi 40 (1): 113. https://doi.org/10.14203/j.baca.v40i1.470.

Maryono, and Sri Junandi. 2012. "Indonesian Journal of Chemistry 2007-2011: Analisis Kolaborasi Dan Institusi (Indonesian Journal of Chemistry 2007-2011: Collaboration and Institution Analysis)." Visi Pustaka 14 (3): 13-23.

Maryono, Maryono, and Surajiman Surajiman. 2017. "Kolaborasi Internal, Domestik Dan Internasional Serta Korelasinya Dengan Sitasi Yang Diperoleh: Analisis Publikasi UGM Di Scopus." Berkala Ilmu Perpustakaan Dan Informasi $13 \quad$ (2): 166. https://doi.org/10.22146/bip.27492.

Mertler, Craig A. 2017. “Action Research: Improving Schools and Empowering Educators.” Sage Publications Ltd.

Nalbaho, Kalarensi. 2015. "Kolaborasi Pustakawan Dan Ilmuwan Di Perguruan Tinggi Dalam Community of Practice (CoP)." Al-Maktabah 14: 20-29.

Nani Rahayu, Rochani. 2018. "Kolaborasi Penulis Dalam Berita Biologi Jurnal Ilmu-Ilmu Hayati 2011-2016." Khizanah Al-Hikmah: Jurnal Ilmu Perpustakaan, Informasi, Dan Kearsipan 5 (2): 196-206. https://doi.org/10.24252/kah.v5i2a7.

Nappu, Syamsiarna, Ratna Dewi, and Herlina Daddi. 2019. "Peningkatan Kemampuan Guru Dalam Melaksanakan Penelitian Tindakan Kelas.” Jurnal Dedikasi 21 (1).

Nashihuddin, Wahid, and Dwi Ridho Aulianto. 2016. "Pengelolaan Terbitan Berkala Ilmiah Sesuai Ketentuan Akreditasi: Upaya Menuju Jurnal Terakreditasi Dan Bereputasi Internasional." Jurnal Pustakawan Indonesia 15 (1-2): 83-98. https://doi.org/10.13140/RG.2.1.1500.3927.

Nasution, Mahyuddin K. M. 2017. "Jurnal Nasional." ResearchGate, no. 21120118130055. https://doi.org/10.13140/RG.2.2.15424.43526/1.

Natakusumah, Engkos Koswara. 2014. "Penentuan Kolaborasi Penelitian Dan Distribusi Pengarang Pada Jurnal Teknologi Indonesia (the Determinations of Research Collaboration and Authors Distribution in the Jurnal Teknologi Indonesia).” Baca: Jurnal Dokumentasi Dan Informasi 35 (1): 15-24. http://jurnalbaca.pdii.lipi.go.id/index.php/baca/article/view/147.

Nizar, Muhammad. 2016. "Proses Entrepreneurship, Kolaborasi Inovasi, Penciptaan Kekayaan Di Dalam Organisasi Bisnis.” Jurnal Istiqro 2 (2): 91-103.

Nugraha, Fajar, Wiwit Agus Triyanto, Muhammad Arifin, and Yuniarsi Rahayu. 2019. "Rancang Bangun Sistem Informasi Penilaian Beban Kerja Dosen." Simetris: Jurnal Teknik Mesin, Elektro Dan Ilmu Komputer 10 (1): 405-12. https://doi.org/10.24176/simet.v10i1.3312.

Nur'aini. 2013. “Perbandingan Pemanfaatan Jurnal Tercetak Dengan Jurnal Elektronik Untuk Kebutuhan Informasi Mahasiswa Di Perpustakaan Universitas Sumatera Utara Cabang Kedokteran." Repository Universitas Sumatera Utara.

Nurdinintya Athari S., Tien Fabrianti K., Albi Fitransyah. 2015. "Pengelompokan Tim Pengembang Berdasarkan Kriteria Perilaku Manusia Dalam Kolaborasi Pengembangan Perangkat Lunak." Jurnal Rekayasa Sistem \& Industri 2 (April): 59-65.

Permendiknas. 2011. "PERMENDIKNAS No 22 Tahun 2011 Tentang Terbitan Berkala Ilmiah." Menteri Pendidikan Nasional, no. 2009: 11-50. 
Pohan, Fitrianti. 2014. "Analisis Bibliometrika Terhadap Jurnal Ilmiah Terbitan Indonesia Pada Database Scimago Journals And Country Rank." Repository Universitas Sumatera Utara. http://repository.usu.ac.id/handle/123456789/45666.

Prasetyadi, Abdurrakhman, and D.W. Ari Nugroho. 2014. "Ilmiah LIPI Bidang Informatika Dan Kebumian." Visi Pustaka 16 (1): 5-13.

Rahayu, Rochani Nani, and Rulina Rachmawati. 2016. "Kolaborasi Dan Produktivitas Penulis Artikel Visi Pustaka 2000 - 2014." Baca: Jurnal Dokumentasi Dan Informasi 36 (2): 141. https://doi.org/10.14203/j.baca.v36i2.208.

Rahayu, Rochani Nani, and Tupan Tupan. 2018. "Kolaborasi Dan Produktivitas Penulis Pada Prosiding Lokakarya Nasional Dokumentasi Dan Informasi PDII LIPI Periode 2013-2017." Lentera Pustaka: Jurnal Kajian Ilmu Perpustakaan, Informasi Dan Kearsipan 4 (2): 57-66. https://doi.org/10.14710/lenpust.v4i2.20432.

Rahmawati, Laili Etika, and Najma Thalia. 2013. "Upaya Meningkatkan Kemampuan Menulisis Imiah Mahasiswa S1 Fisioterapi UMS Dengan Metode Kolaborasi Pada Tahun Akademik 2012/2013." Jurnal Penelitian Humaniora 13 (2): 178-89.

Rasmila. 2017. "Tingkat Kolaborasi Dan Alasan Pengarang Berkolaborasi Studi Kasus Pada Jurnal Reference Service Review Tahun 2012-2016.” Repository Universitas Sumatera Utara, 7-37.

Ricoida, Desy Iba, Denny, and Solihin. 2019. "Sistem Informasi Penilaian Kinerja Dosen Dengan Metode Extreme Programming (Studi Kasus: STMIK MDP).” Jurnal Teknik Informatika Dan Sistem Informasi 5 (2): 219-28.

Rohanda, and Lilis Ruslina. 2018. "Scientific Communication Reviewed From Aspect of Authorship Collaboration in Sosiohumaniora Journal." Perpustakaan Dan Sains Informasi 8 (2).

Rohanda, and Yunus Winoto. 2019. "Analisis Bibliometrika Tingkat Kolaborasi, Produktivitas Penulis, Serta Profil Artikel Jurnal Kajian Informasi \& Perpustakaan Tahun 2014-2018." Pustabiblia: Journal of Library and Information Science 3 (1): 1. https://doi.org/10.18326/pustabiblia.v3i1.1-16.

Rokhmah, Noor Ariyani, and Anggorowati Anggorowati. 2017. "Komunikasi Efektif Dalam Praktek Kolaborasi Interprofesi Sebagai Upaya Meningkatkan Kualitas Pelayanan.” Journal of Health Studies 1 (2): 65-71. https://doi.org/10.31101/jhes.186.

Rusdi, Jack Febrian. 2017. Kolaborasi Pariwisata Bandung Raya. Indonesia Tourism Journalist Association.

Rusdi, Jack Febrian. 2019. “Articles of Author's Collaboration in Indonesia.” Mendeley Data, V1. https://doi.org/10.17632/dj7ys332db.1.

Rusdi, Jack Febrian, Sazilah Salam, Nur Azman Abu, Tedja Gurat Baktina, R Gumilar Hadiningrat, Budi Sunaryo, Arlinda Rusmartiana, et al. 2019. "ICT Research in Indonesia." SciTech Framework 1: 1-23. http://scitech.id/index.php/framework/article/view/2.

Rusdi, Jack Febrian, Sazilah Salam, Nur Azman Abu, Shahrin Sahib, Muchammad Naseer, and Abdul Aziz Abdullah. 2019. "Drone Tracking Modelling Ontology for Tourist Behavior." Journal of Physics: Conference Series 1201 (1): 012032. https://doi.org/10.1088/17426596/1201/1/012032.

Safitri, Dewi. 2011. "Kolaborasi Pengarang Pada The International Journal Of Geomechanics 
Tahun 2006-2010.” Repository Universitas Sumatera Utara.

Seftyono, Cahyo. 2018. "Masyarakat Akademik Dalam Isu Penerbitan Ilmiah Di Indonesia." SocArXiv. https://doi.org/10.31235/osf.io/89wy6.

Sholihah, Umi. 2018. "Teknik Peer-Review Melalui Google Docs: Alternatif Piranti Kolaborasi Dalam Menulis." Widya Wacana: Jurnal Ilmiah 13 (2): 61-68. https://doi.org/10.33061/ww.v13i2.2262.

Sofyani, Hafiez, and Ietje Nazaruddin. 2019. "Pengaruh Implementasi Sistem Pengukuran Kinerja Dosen Dan Kejelasan Peran Terhadap Kinerja Dosen: Sebuah Studi Pengujian Efek Mediasi." Jurnal Reviu Akuntansi Dan Keuangan 9 (1): 31-41. https://doi.org/10.22219/jrak.v9i1.42.

Subramanyam, K. 1983. "Bibliometric Studies of Research Collaboration: A Review." Journal of Information Science 6 (1): 33-38. https://doi.org/10.1177/016555158300600105.

Suhardi, Iwan, Sapto Haryoko, and Hendra Jaya. 2016. "Pengembangan Sistem Pakar Menggunakan Metode Forward Chaining Untuk Penelusuran Dan Publikasi Manuskrip Ilmiah Pada Jurnal Internasional Bereputasi." Prosiding Seminar Nasional Lembaga Penelitian Universitas Negeri Makassar.

Suryantini, Heryati, and Nurdiana Nurdiana. 2017. "Kolaborasi Peneliti Bidang Bioteknologi Dan Sumber Daya Genetik Pertanian Pada Jurnal Agrobiogen.” Jurnal Perpustakaan Pertanian 25 (2): 63. https://doi.org/10.21082/jpp.v25n2.2016.p63-70.

Syarianah. 2016. "Produktivitas Peneliti Pusat Penelitian Dan Pengembangan Perikanan Budidaya : Suatu Kajian Pada Jurnal Riset Akuakultur.” Jurnal Pari 2 (1): 16-24.

Tanari, Amanda, Andreas Handojo, and Justinus Andjarwirawan. 2019. "Aplikasi Pencarian Jurnal Ilmiah Dengan Term Frequency- Inverse Document Frequency.” Jurnal Infra 7 (1).

Tuhuteru, Hennie, and Ade Iriani. 2018. "Analisis Kolaborasi Penelitian Ilmiah Dosen Fakultas X Dengan Social Network Analysis (SNA)." Jurnal Teknik Informatika Dan Sistem Informasi 4 (1): 149-58. https://doi.org/10.28932/jutisi.v4i1.758.

Wahyudi, Sucihatiningsih Dian Wisika Prajanti, Anggyi Trisnawan, Martanto Setyo Husodo, Muhammad Kurniawan, and Karnowo. 2016. "Pengembangan Software Untuk Sistem Validasi Kategori Jurnal Internasional Terindeks Scopus Dan Jurnal Nasional Terakreditasi.” Jurnal Sains Dan Teknologi (Sainteknol) 16 (2): 221-30.

Widuri, Noorika Retno, and Abdurrakhman Prasetyadi. 2018. "Tingkat Kolaborasi, Produktivitas Penulis Dan Artikel Metrik Pada Jurnal Mechatronics,Electrical Power, and Vehicular Technology." Berkala Ilmu Perpustakaan Dan Informasi 14 (1): 62. https://doi.org/10.22146/bip.33408.

Windayana, Husain. 2016. "Penelitian Tindakan Sekolah." EduHumaniora | Jurnal Pendidikan Dasar Kampus Cibiru 4 (1). https://doi.org/10.17509/eh.v4i1.2815.

Wulan, Sri. 2014. "Produktivitas Dan Tingkat Kolaborasi Penulis Dalam Karya Tulis Ilmiah Peneliti Bidang Zoologi, Puslit Biologi-Lipi 2005-2010.” Visi Pustaka 16 (2): 176-84.

Wulan, Sri. 2017. "Pola Penulisan Dan Kolaborasi Penelitian Pada Jurnal Treubia." BACA: Jurnal Dokumentasi Dan Informasi 38 (2): 157. https://doi.org/10.14203/j.baca.v38i2.331.

Wullum Nielsen, Mathias, and Love Börjeson. 2019. "Gender Diversity in the Management Field: Does It Matter for Research Outcomes?" Research Policy 48 (7): 1617-32. 
https://doi.org/10.1016/j.respol.2019.03.006.

Xiang, Zheng. 2018. "From Digitization to the Age of Acceleration: On Information Technology and Tourism." Tourism Management Perspectives 25 (September): 147-50. https://doi.org/10.1016/j.tmp.2017.11.023.

Yaman, Aris, Ambar Yoganingrum, Yaniasih Yaniasih, and Slamet Riyanto. 2019. "Tinjauan Pustaka Sistematis Pada Basis Data Pustaka Digital: Tren Riset, Metodologi, Dan Coverage Fields." Baca: Jurnal Dokumentasi Dan Informasi 40 (1): 1-20. https://doi.org/10.14203/J.BACA.V40I1.481.

Yanti, and Krismayani Ika. 2018. "Pengaruh Aksesibilitas Jurnal Elektronik Berlanggan Terhadap Kepuasan Pemustaka Di UPT Perpustakaan Universitas Diponegoro Semarang.” Jurnal Ilmu Perpustakaan 7 (2). 